Running head: DARIER DISEASE: GENOTYPE-PHENOTYPE

\title{
Genotype-phenotype correlations in Darier disease - a focus on the neuropsychiatric phenotype
}

Katherine Gordon-Smith ${ }^{1}$, Elaine Green ${ }^{2}$, Detelina Grozeva ${ }^{3}$, Sherine Tavadia ${ }^{4}$, Nick

Craddock $^{3}$, Lisa Jones ${ }^{1}$

${ }^{1}$ Department of Psychological Medicine, University of Worcester, Worcester, UK

${ }^{2}$ School of Biomedical and Healthcare Sciences, Plymouth University, Plymouth, UK

${ }^{3}$ Institute of Psychological Medicine \& Clinical Neurosciences, Cardiff University, Cardiff, UK

${ }^{4}$ Department of Dermatology, University Hospital Crosshouse, Kilmarnock, Ayrshire, UK

\section{Correspondence}

Lisa Jones

Department of Psychological Medicine, University of Worcester, Henwick Grove, Worcester, WR2 6AJ, UK

Email: lisa.jones@worc.ac.uk

Telephone: +44 (0)1905 542801 Fax: +44 (0)1905 855589

\section{Funding information}

Wellcome Trust 


\section{Abstract}

Darier Disease (DD) is an autosomal dominant skin disorder caused by mutations in ATP2A2 encoding the sarco/endoplasmic reticulum $\mathrm{Ca}^{2+}$ ATPase isoform 2 (SERCA2). Evidence of a population-level association between DD and psychiatric disorders suggests that mutations in ATP2A2 may have pleiotropic effects on the brain as well as skin. Evidence of genotype-phenotype relationships between ATP2A2 mutations and neuropsychiatric phenotypes would further support this suggestion.

We investigated genotype-phenotype correlations between lifetime neuropsychiatric features and $A T P 2 A 2$ mutation type (dichotomized into likely gene disrupting (LGD) or protein altering (PA)) in 75 unrelated individuals with DD. We also looked for evidence of clustering of mutations within SERCA2 according to neuropsychiatric features.

Combining our data with the existing literature, the rate of LGD mutations was found to be significantly higher among DD cases/families with bipolar disorder, schizophrenia or affective psychosis $(\mathrm{p}=0.011)$. We also found a significant relationship between mutations located in the S4-M4 region of the protein and the presence of a severe neuropsychiatric phenotype $(\mathrm{p}=0.032)$.

Our findings add support to the hypothesis that Darier-causing mutations in ATP2A2 confer susceptibility to neuropsychiatric dysfunction, in particular severe psychiatric illness. This, together with evidence from research on common polymorphisms confirms $A T P 2 A 2$ as a gene at which variation influences susceptibility to major psychiatric illness. (word count $\mathrm{n}=206$ )

Key words: Darier disease, neuropsychiatric features, genotype-phenotype correlations 


\section{INTRODUCTION}

Darier disease (DD) is a rare autosomal dominant inherited skin disorder with an estimated average prevalence of between 1 in 100,000 to 30,000 (Svendsen \& Albrectsen, 1959; Tavadia, Mortimer, \& Munro, 2002) and usually presents in the second decade with no sex difference (Burge \& Wilkinson, 1992). It is characterised by hyperkeratotic papules in seborrheic areas, palmo-plantar pits and nail dystrophy. DD is inherited with a high penetrance although the phenotypic expression is variable (Munro, 1992).

The disease is caused by mutations in the gene ATP2A2 (Sakuntabhai, Ruiz-Perez, et al., 1999) which encodes the sarco/endoplasmic reticulum $\mathrm{Ca}^{2+}$ ATPase isoform 2 (SERCA2), a calcium pump located in the endoplasmic reticulum (ER) membrane which plays a key role in $\mathrm{Ca}^{2+}$ homeostasis. The protein contains five major domains which include 11 transmembrane helices (M1-M11), 5 stalks (S1-S5) and three cytoplasmic domains; the actuator $(\mathrm{A})$ domain, the nucleotide ATP-binding $(\mathrm{N})$ domain and the phosphorylation (P) domain. To date well over 200 different Darier-causing mutations have been identified throughout $A T P 2 A 2$ including missense, nonsense, substitutions, and both frame-shift and in-frame insertions and deletions (Human Gene Mutation Database http://www.hgmd.org). Generally, these mutations do not seem to cluster within potential 'hot-spot' regions throughout the primary sequence of the SERCAb molecule and most are unique within individual families.

The co-occurrence of neuropsychiatric features, including depression, bipolar disorder, epilepsy and learning difficulties, with DD has frequently been reported (Burge \& Wilkinson, 1992; Cederlöf, Bergen, et al., 2015; Cederlöf, Karlsson, et al., 2015; Denicoff, Lehman, Rubinow, Schmidt, \& Peck, 1990; Dodiuk-Gad et al., 2014, 2016; 
Gordon-Smith et al., 2010; Medansky \& Woloshin, 1961; Ringpfeil et al., 2001). The nature of this co-occurrence has long been debated in the literature with a number of potential explanations being put forward. A seemingly plausible explanation is that the high psychiatric morbidity observed in DD is a direct psychological consequence of having a chronic skin disorder. However, our previous investigations into the neuropsychiatric phenotype in DD and the work of others have not found any significant relationships between psychiatric phenotypes and DD clinical features including disease severity suggesting this argument alone cannot account for the association (Dodiuk-Gad et al., 2016; Gordon-Smith et al., 2010).

In recent years, studies have found evidence of a population-level association between DD and psychiatric disorders - specifically mood disorders, including bipolar disorder, and schizophrenia (Cederlöf, Bergen, et al., 2015; Dodiuk-Gad et al., 2016; GordonSmith et al., 2010). This included a matched cohort study based on Swedish national registers that found individuals with DD had a 4.3 and 2.3 times higher risk of bipolar disorder and schizophrenia respectively than individuals in the general population (Cederlöf, Bergen, et al., 2015). These findings suggest that mutations in ATP2A2 have pleiotropic effects in the skin and brain and confer susceptibility to neuropsychiatric features. This theory would be strongly supported by evidence of genotype-phenotype relationships between $A T P 2 A 2$ mutation type and co-occurrence of neuropsychiatric phenotypes.

To date, a small number of studies have examined genotype-phenotype correlations with the neuropsychiatric phenotypes observed in DD (Bchetnia et al., 2009; Dodiuk-Gad et al., 2016; Jacobsen et al., 1999; Nellen et al., 2016; Ringpfeil et al., 2001; Ruiz-Perez et 
al., 1999; Sakuntabhai, Burge, Monk, \& Hovnanian, 1999) with no clear and consistent correlations being identified. Difficulties in establishing these relationships may be due to a number of reasons including small sample sizes (ranging from 8-49 cases) and the use of diverse methods to measure neuropsychiatric phenotypes. The lack of consistent application of any standardized method of grouping the types of mutations has also been a major methodological impediment. A recent review of the literature divided reported Darier-causing mutations into two categories: (a) likely gene disrupting (LGD) mutations (frameshift, splice site, nonsense, gain of stop codon or loss of start codon) and (b) protein altering (PA) mutations (missense or inframe-insertion/deletions) (Nakamura et al., 2016). This study found significantly higher rates of LGD mutations in Darier cases with reported co-occurring neuropsychiatric features than in those without such features. A single study has reported a non-random clustering of mutations in the last half of $A T P 2 A 2$ and a neuropsychiatric phenotype (in a sample of 19 unrelated individuals with DD) (Jacobsen et al., 1999). However no other genotype-phenotype associations between mutation location along the primary structure of the gene and the presence of neuropsychiatric features have been reported in other samples (Dodiuk-Gad et al., 2016; Nellen et al., 2016; Ringpfeil et al., 2001) including the recent literature survey (Nakamura et al., 2016). The authors of the survey noted that this lack of association would be reasonable as LGD mutations in any exon could result in similar molecular consequences.

We have previously reported a systematic investigation of the neuropsychiatric characteristics in a large UK sample of unrelated individuals with DD (Gordon-Smith et al., 2010) and more recently reported the disease causing sequence variants of ATP $2 A 2$ within this large sample (Green et al., 2013). Although these mutations were included in 
the recent analysis by Nakamura et al. (2016) the associated neuropsychiatric phenotypes were unknown to the authors at the time. In the current study we investigated potential correlations between mutation type (LGD vs PA) and neuropsychiatric phenotypes among 75 unrelated individuals with DD. This is the largest such study to date. This large sample has also enabled us to look for evidence of clustering of mutations within the SERCA2 protein among individuals with similar neuropsychiatric phenotypes and we report that here. Using this clustering approach may be a more useful way of examining genotypephenotype correlations with neuropsychiatric phenotypes in DD given the likely complex nature of the associations. Finally we combined our sample with previously reported DD cases/families in the literature to date to establish whether any genotype-phenotype correlations observed were enriched in the combined dataset.

\section{MATERIALS AND METHODS}

\subsection{Recruitment of participants}

A detailed description of the sample has previously been published (Gordon-Smith et al., 2010). In summary, 100 unrelated individuals with a diagnosis of DD were recruited throughout the United Kingdom mainly via dermatology services and the U.K. Darier Support Group. The study was approved by the Multi-Centre Research Ethics Committee for Wales (MREC).

\subsection{Neuropsychiatric assessment}

Neuropsychiatric assessments were conducted in a single session by a trained research psychologist (KGS). Psychiatric symptomatology, including history of suicidal thoughts/attempts, was measured using an adapted version of Schedules for Clinical 
Assessment in Neuropsychiatry interview (Wing et al., 1990). This information was supplemented by psychiatric notes and/or general practice case-notes. Lifetime-ever psychiatric diagnoses were made according to the Diagnostic and Statistical Manual of Mental Disorders, Fourth Edition, (DSM-IV) (American Psychiatric Association, 2000). Three experienced research psychologists/psychiatrists (KGS, LJ, NC) made the psychiatric ratings independently, using written case vignettes, and consensus was reached. Inter-rater reliability was high with mean kappa statistics of 0.86 and 0.93 for DSM-IV diagnoses and suicidal ideation respectively. Lifetime history of neurological symptoms and disorders was assessed using a brief interview checklist, supplemented by hospital and/or general practice case-notes.

\subsection{ATP2A2 variant identification}

A DNA sample was obtained from 95 individuals. 66 potentially pathogenic mutations in $A T P 2 A 2$ were identified in 74 individuals. No potentially pathogenic variant in ATP $2 A 2$ was identified in the remaining 21 individuals. One of the five remaining individuals from whom a sample was not collected had taken part in a previous study (Sakuntabhai, RuizPerez, et al., 1999) from which the potential pathogenic variant was supplied. For further details on the identification of mutations see our previous publication (Green et al., 2013).

\subsection{Genotype-phenotype correlations}

According to the definitions used in a recent study (Nakamura et al., 2016) mutations were classified as either likely gene disrupting (LGD) (frameshift insertions/deletions, mutations predicted to alter a splice codon, nonsense mutations, gain of stop codon or loss of start codon) or protein altering (PA) (missense or inframe-insertion/deletions). 
Rates of LGD and PA mutations were compared between individuals stratified according to the presence or absence of each of the following key lifetime neuropsychiatric features:
i) any neuropsychiatric phenotype,
ii) any psychiatric disorder meeting DSM-IV criteria,
iii) contact with a neurologist or neurological procedure,
iv) suicide attempt,
v) severe neuropsychiatric phenotype (bipolar disorder, schizophrenia or affective psychosis).

\begin{abstract}
All mutations detected were mapped onto a schematic diagram of the SERCA2b protein to look for evidence of possible clustering of mutations according to occurrence within individuals of similar neuropsychiatric features.
\end{abstract}

\title{
2.5 Combined analysis with existing literature
}

We combined our sample with the previously reported DD cases/families in the literature with an identified Darier causing mutation ( $\mathrm{n}=384$ including the current sample). Within the combined sample we

1) Compared rates of LGD and PA mutations according to the absence or presence of a reported severe neuropsychiatric phenotype

2) Compared the rates of mutations located in specific functional domains of the SERCA2 protein according to the absence or presence of a reported severe neuropsychiatric phenotype

A severe neuropsychiatric phenotype was rated as present if the index case and/or a family member with DD was reported as having a diagnosis of bipolar disorder, 
schizophrenia or affective psychosis. All members of the same family will have the same DD causing mutation and therefore a shared diathesis. Within this analysis we also included an unpublished missense mutation (P312R) identified in an individual with DD and bipolar disorder seen by our research group as part of our ongoing mood disorders research programme who was not included in the current study as they were identified on the basis of having bipolar disorder rather than on the basis of having DD.

\subsection{Statistical analyses}

Groups were compared using chi-square tests or Fisher's exact tests where $20 \%$ or more of the cells in a chi-square table had an expected count of $<5$. For significant findings $(\mathrm{p}<0.05)$ odds ratios with $95 \%$ confidence intervals were calculated. Statistical analyses were carried out using SPSS for Windows.

\section{RESULTS}

\subsection{Current sample ( 75 cases)}

Table 1 summarises the DD clinical and neuropsychiatric features in the sample along with the type and location of $A T P 2 A 2$ mutation identified and mutation classification according to the LGD and PA groupings.

In our 75 cases we found a consistent non-significant trend for a higher prevalence of LGD mutations among individuals with a lifetime occurrence of each of the neuropsychiatric phenotypes compared with individuals with the absence of the neuropsychiatric phenotype (any neuropsychiatric phenotype $45.5 \%$ vs. $35 \%$, $p=0.418$; any psychiatric disorder meeting DSM-IV criteria $46 \%$ vs. $38 \%, \mathrm{p}=0.480$; contact with a neurologist or neurological procedure $53 \%$ vs $36 \%$, $\mathrm{p}=0.127$; suicide attempt $50 \%$ vs. 
$41 \%, p=0.733$; severe neuropsychiatric phenotype $75 \%$ vs. $41 \%, p=0.307$ ). (Figure 1 and Table 2).

We observed possible clustering of mutations according to individuals with similar neuropsychiatric phenotypes (Figure 2) but none reached statistical significance:

- All four individuals with mutations located in the functional ' $\mathrm{A}$ ' domain between the stalk 2 and stalk 3 domains of the protein had a history of a psychiatric disorder severe enough to warrant contact with psychiatric services (IDs 11, 12, $13 \& 14)$.

- Three individuals with the same missense mutation at one of the seven $\mathrm{Ca}^{2+}$ binding sites in the M5 domain all had a DSM-IV diagnosis of a mood disorder (ID 54, 55, \& 56).

- Two individuals with frameshift mutations one base pair apart in the S4 (Stalk 4) domain of the protein both had a history of suicide attempts in addition to having idiopathic epilepsy (ID 19) and an extensive psychiatric history including major depressive disorder and investigations for a blackout (ID 20).

\subsection{Analysis of combined data with existing literature (384 cases)}

In the combined analysis with existing literature, the rate of LGD mutations was significantly higher where a history of a severe neuropsychiatric phenotype (bipolar disorder, schizophrenia or affective psychosis) was reported in either the index case and/or family member with DD compared those without a reported history; $68 \%$ vs. $40.5 \%, \mathrm{p}=0.011(\mathrm{OR} 3.15,95 \%$ CI 1.25-7.91) (Table 3). This remained significant when we only included the 14 cases of bipolar disorder; $71.4 \%$ vs. $41.0 \%, p=0.024$ (OR 3.44, 95\% CI 1.10-10.76). With respect to mutation location, no significant genotype- 
phenotype correlations were found with mutations located in the ' $A$ ' domain of the SERCA2 protein or calcium binding sites. However, the rate of mutations located between the stalk 4 and transmembrane helix 4 (S4-M4) region was significantly higher where a history of a severe neuropsychiatric phenotype was reported compared to where not; $14 \%$ vs. $3 \%$, Fisher's=0.032 (OR 5.66, 95\% CI 1.41-21.88). When this analysis was narrowed down further to only include PA, mutations this became more significant: $43 \%$ vs. $4 \%$, Fisher's $=0.003$ (OR 19.22, 95\% CI 3.67-100.6). A summary of all mutations identified by our research group and those in the literature located within the S4-M4 region is presented in Figure 3 along with brief descriptions of all known neuropsychiatric features reported among individuals/families with DD the mutations. This includes two families with bipolar disorder and an individual with schizophrenia (Figure 3).

\section{DISCUSSION}

Our genotype-phenotype investigations have been carried out in the largest sample of individuals with DD to date. Consistent with the recent prior report (Nakamura et al., 2016), we found that LGD mutations were relatively more common in those DD individuals with neuropsychiatric phenotypes than those without such phenotypes. We had only four cases in our sample that met the prior report's definition of 'psychosis' (bipolar disorder, schizophrenia and affective psychosis). Of these four cases, three had LGD mutations and one had a PA mutation. Because of the small numbers, this difference compared to those with DD without 'psychosis' does not meet statistical significance. However, when we add our new data to the existing literature the statistical significance of the finding that the rate of LGD mutations is higher among cases/families with this severely defined neuropsychiatric phenotype is strengthened $(\mathrm{p}=0.011$, compared with the 
previously reported $\mathrm{p}=0.026$ (Nakamura et al., 2016) which although included our cases the neuropsychiatric features associated with the mutations were unknown to the authors), and this association remains significant even when the phenotype definition is narrowed to include only bipolar disorder. We also observed in our sample that mutations in individuals with similar neuropsychiatric phenotypes tended to cluster in certain locations within the SERCA2 protein but none reached statistical significance. In our combined analysis we did however find a significant relationship with mutations located in the S4M4 region of the protein and the presence of a severe neuropsychiatric phenotype. Furthermore when this analysis was repeated with only PA mutations the association remained significant. This finding has not previously been reported.

It is highly plausible that mutations in ATP2A2 could be involved in conferring susceptibility to neuropsychiatric illness since the gene is widely expressed in the brain. The dual role of the SERCA2b protein in intracellular $\mathrm{Ca}^{2+}$ signaling and in the synthesis and post-translational modification of proteins within the endoplasmic reticulum (ER) also provides support for this suggestion. Intracellular $\mathrm{Ca}^{2+}$ signaling has been shown to play a role in a range of neuronal functions including neuronal excitability, neurotransmitter release, gene expression, neuronal growth and synaptic plasticity (Berridge, 2002; Berridge, Bootman, \& Lipp, 1998; Verkhratsky, 2005). Genome-wide association studies (GWAS) have suggested the role of calcium signaling and calciumchannel activity in the pathogenesis of a number of major psychiatric disorders, including bipolar disorder and schizophrenia (Cross-Disorder Group of the Psychiatric Genomics Consortium \& Genetic Risk Outcome of Psychosis (GROUP) Consortium, 2013; Ferreira et al., 2008) with a more recent GWAS identifying ATP2A2 as a schizophrenia-associated loci (Ripke et al., 2014). 
A recent study showing Darier keratinocytes display the hallmarks of constitutive ER stress with increased sensitivity to ER stressors lead the authors of the study to suggest DD should be classed as an ER stress related disease (Savignac, Simon, Edir, Guibbal, \& Hovnanian, 2014). There is also evidence for the role of ER stress responses in neuropsychiatric disorders. Lymphoblastoid cell lines from individuals with bipolar disorder have showed an impaired response to ER stress (Hayashi et al., 2009; Pfaffenseller et al., 2014; So, Warsh, \& Li, 2007). Lithium is the main mood stabiliser used in the treatment of bipolar disorder and a recent study identified the response to ER stress as a lithium-regulated gene network (Breen et al., 2016). It is possible that the function of SERCA2b pumps may be more critical in the skin and the brain than in other tissues. Both tissues may have a particular susceptibility to a reduction in SERCA2b activity possibly relating to changes in $\mathrm{ER} \mathrm{Ca}^{2+}$ concentration and ER functioning.

A limitation of the current analysis is that despite being the largest study to date, the small stratified group sizes in our genotype-phenotype analyses limits the power to detect significant relationships. Combining our sample with the existing literature enabled us to address this. However, previous studies of DD cases/families in the literature have not all recorded and/or reported neuropsychiatric features. Similarly, where neuropsychiatric features have been reported previously in the literature, in many cases only brief descriptions are provided. Ours and other studies have not included detailed assessments of the presence of neurological features such as hearing difficulties. Further studies systematically assessing neuropsychiatric features in individuals with DD are warranted including the administration of specific neurological tests such as audiograms. 
We have found evidence to support the suggestion that mutations in ATP2A2 in addition to causing DD, confer susceptibility to neuropsychiatric features in individuals with DD. Given the complex nature of the disorders it is likely that the pleiotropic effects occur in association with other modifying factors. Our findings suggest that DD causing mutations as well as other genes encoding proteins in the same biological system as, and/or encoding proteins with a similar function to, SERCA2b would be good candidates for further investigations of potential involvement in predisposing individuals to developing severe neuropsychiatric illness.

\section{ACKNOWLEDGMENTS}

We are grateful to the Wellcome Trust for funding this study. We thank the dermatologists and other health professionals who helped recruit participants in particular the invaluable contributions of Dr Sue Burge and Professor Colin Munro, and also Mrs Jenny Davies from the UK Darier support group. We also thank all the participants who gave their time to help in this study. 
Table 1 Clinical and neuropsychiatric features in 75 individuals with Darier Disease and type and location of $A T P 2 A 2$ mutations

\begin{tabular}{|c|c|c|c|c|c|c|c|c|c|}
\hline ID & Sex & Severity of DD & Neuropsychiatric phenotype & Location & Nucleotide and alteration & Amino acid alteration & Type & Protein domain & $\begin{array}{c}\text { LGD or } \\
\text { PA } \\
\text { mutation }\end{array}$ \\
\hline 1 & F & Moderate & & Exon 1 & $1 \mathrm{~A}>\mathrm{G}$ & Met1V & Missense & Start codon & LGD \\
\hline 2 & M & Moderate & & Exon 1 & $34+57$ ins & $\begin{array}{l}\text { V29Met ins repeat of } \\
\text { previous } 19 \text { amino acids }\end{array}$ & In-frame insertion & A domain & PA \\
\hline 3 & M & Moderate & $\begin{array}{l}\text { Investigations for hearing } \\
\text { problems. }\end{array}$ & Exon 1 & 48 del14 / ins 11 & V18X & Frameshift (PTC +1aa) & A domain & LGD \\
\hline 4 & M & Mild & & Exon 1 & $94 \mathrm{C}>\mathrm{T}$ & L32F & Missense & A domain & PA \\
\hline 5 & M & Mild & Epilepsy. & Intron 2 & $137-3 C>G$ & & Splice site & & LGD \\
\hline 6 & $\mathrm{~F}$ & Moderate & $\begin{array}{l}\text { Bipolar I disorder }{ }^{\mathrm{a}} \text {. Investigations } \\
\text { for periods of unconsciousness. }\end{array}$ & Exon 3 & 142 Ins 18 & & Frameshift (PTC+14aa) & S1 & LGD \\
\hline 7 & $\mathrm{~F}$ & Mild & Major depressive disorder ${ }^{\mathrm{a}}$. & Exon 3 & $167 A>G$ & Q56R & Missense & M1 & PA \\
\hline 8 & $\mathrm{~F}$ & Severe & Major depressive disorder. & Exon 3 & $194 \mathrm{~T}>\mathrm{C}$ & L65S & Missense & M1 & PA \\
\hline 9 & $\mathrm{~F}$ & Moderate & Dysthymic disorder. & Intron 3 & $219+5$ insAA & & Splice site & & LGD \\
\hline 10 & M & Moderate & $\begin{array}{l}\text { Investigations for hearing } \\
\text { problems. }\end{array}$ & Intron 5 & $325-2 A>G$ & & Splice site & M2 & LGD \\
\hline 11 & $\mathrm{~F}$ & Moderate & Bipolar I disorder ${ }^{\mathrm{a}}$. & Intron 6 & $464-1 \mathrm{~A}>\mathrm{C}$ & & Splice site & A domain & LGD \\
\hline 12 & $\mathrm{~F}$ & Moderate & Major depressive disorder ${ }^{\mathrm{a}}$. & Exon 6 & $490 \mathrm{~A}>\mathrm{G}$ & R164G & Missense & A domain & PA \\
\hline 13 & $\mathrm{~F}$ & Moderate & Major depressive disordera ${ }^{\mathrm{a}}$. & Exon 6 & 543delA & & Frameshift (PTC+42aa) & A domain & LGD \\
\hline 14 & M & Moderate & $\begin{array}{l}\text { Depression NOS }{ }^{\text {a }} \text {. Suicide } \\
\text { attempt. }\end{array}$ & Exon 8 & $698 \mathrm{G}>\mathrm{T}$ & G233V & Missense & A domain & PA \\
\hline 15 & F & Moderate & & Exon 8 & 826 del 15 & Del 276-300 (IGHFN) & In-frame deletion & M3-M4 lumenal & PA \\
\hline 16 & $\mathrm{~F}$ & Severe & Depression NOS. & Exon 8 & $923 \mathrm{C}>\mathrm{A}$ & $\mathrm{P} 308 \mathrm{H}$ & Missense & M4 & PA \\
\hline 17 & M & Moderate & Treatment for hearing problems. & Exon 8 & $925 \mathrm{G}>\mathrm{A}$ & E309K & Missense & M4 & PA \\
\hline 18 & $\mathrm{~F}$ & Severe & & Exon 8 & $929 \mathrm{G}>\mathrm{T}$ & G310V & Missense & M4 & $\mathrm{PA}$ \\
\hline 19 & $\mathrm{~F}$ & Moderate & $\begin{array}{l}\text { Psychiatric disorder NOS }{ }^{\mathrm{a}} \text {. } \\
\text { Suicide attempt. Epilepsy. } \\
\text { Major depressive disorder }{ }^{\mathrm{a}} \text {. }\end{array}$ & Exon 8 & 948delC & & Frameshift (PTC+65aa) & S4 & LGD \\
\hline 20 & $\mathrm{~F}$ & Moderate & $\begin{array}{l}\text { Suicide attempt. Investigations for } \\
\text { a blackout. }\end{array}$ & Exon 8 & 949del7 & & Frameshift (PTC+65aa) & S4 & LUD \\
\hline 21 & $\mathrm{~F}$ & Mild & & Exon 8 & $958 \mathrm{G}>\mathrm{C}$ & A320P & Missense & S4 & PA \\
\hline 22 & $\mathrm{~F}$ & Moderate & Headaches requiring investigation. & Exon 8 & $1000 \mathrm{C}>\mathrm{T}$ & $\mathrm{R} 334 \mathrm{X}$ & Nonsense & $\mathrm{P}$ domain & LGD \\
\hline 23 & M & Severe & & Exon 8 & $1000 \mathrm{C}>\mathrm{T}$ & $\mathrm{R} 334 \mathrm{X}$ & Nonsense & P domain & LGD \\
\hline 24 & M & Severe & & Exon 8 & $1043 \mathrm{~T}>\mathrm{C}$ & $\mathrm{I} 348 \mathrm{~T}$ & Missense & $\mathrm{P}$ domain & PA \\
\hline
\end{tabular}


Table 1 Clinical and neuropsychiatric features in 75 individuals with Darier Disease and type and location of ATP2A2 mutations

\begin{tabular}{|c|c|c|c|c|c|c|c|c|c|}
\hline ID & Sex & Severity of DD & Neuropsychiatric phenotype & Location & Nucleotide and alteration & Amino acid alteration & Type & Protein domain & $\begin{array}{l}\text { LGD or } \\
\text { PA } \\
\text { mutation }\end{array}$ \\
\hline 25 & $\mathrm{~F}$ & Mild & & Exon 8 & $1070 \mathrm{C}>\mathrm{G}$ & T357R & Missense & P domain & PA \\
\hline 26 & M & Moderate & $\begin{array}{l}\text { Major depressive disorder. } \\
\text { Investigations for hearing } \\
\text { problems. }\end{array}$ & Exon 8 & $1070 \mathrm{C}>\mathrm{A}$ & $\mathrm{T} 357 \mathrm{~K}$ & Missense & $\mathrm{P}$ domain & PA \\
\hline 27 & $\mathrm{~F}$ & Moderate & $\begin{array}{l}\text { Major depressive disorder. } \\
\text { Investigations for suspected } \\
\text { epileptic seizure. }\end{array}$ & Exon 8 & $1095+1 \mathrm{G}>\mathrm{C}$ & & Splice site & $\mathrm{P}$ domain & LGD \\
\hline 28 & $\mathrm{~F}$ & Moderate & $\begin{array}{l}\text { Major depressive disorder' } \\
\text { Suicide attempt. Headaches } \\
\text { requiring investigation. }\end{array}$ & $\begin{array}{l}\text { Exon/ } \\
\text { Intron } 10\end{array}$ & 1228 del 86 & & Deletion & $\mathrm{N}$ domain & LGD \\
\hline 29 & M & Moderate & $\begin{array}{l}\text { Investigations for fainting } \\
\text { episodes. }\end{array}$ & Exon 11 & $1321 \mathrm{~A}>\mathrm{C}$ & $\mathrm{T} 441 \mathrm{P}$ & Missense & $\mathrm{N}$ domain & PA \\
\hline 30 & $\mathrm{~F}$ & Moderate & $\begin{array}{l}\text { Major depressive disorder }{ }^{\mathrm{a}} \text {. } \\
\text { Multiple suicide attempts. } \\
\text { Investigations for blackouts. }\end{array}$ & Exon 11 & $1413 \mathrm{C}>\mathrm{A}$ & $\mathrm{C} 471 \mathrm{X}$ & Nonsense & $\mathrm{N}$ domain & LGD \\
\hline 31 & $\mathrm{~F}$ & Moderate & $\begin{array}{l}\text { Investigations for fainting } \\
\text { episodes. }\end{array}$ & Exon 11 & 1419 del GA & & Frameshift (PTC+1aa) & $\mathrm{N}$ domain & LGD \\
\hline 32 & $\mathrm{~F}$ & Moderate & Major depressive disorder. & Exon 12 & $1484 \mathrm{C}>\mathrm{T}$ & S495L & Missense & $\mathrm{N}$ domain & PA \\
\hline 33 & $\mathrm{~F}$ & Mild & $\begin{array}{c}\text { Major depressive disorder. Suicide } \\
\text { attempt. }\end{array}$ & Exon 12 & $1484 \mathrm{C}>\mathrm{T}$ & S495L & Missense & $\mathrm{N}$ domain & PA \\
\hline 34 & $\mathrm{~F}$ & Mild & Panic disorder. & Exon 12 & 1508del C & & Frameshift $(\mathrm{PTC}+5 \mathrm{aa})$ & $\mathrm{N}$ domain & LGD \\
\hline 35 & $\mathrm{~F}$ & Mild & $\begin{array}{l}\text { Treatment for viral encephalitis. } \\
\text { Bipolar I disordera. Suicide }\end{array}$ & Exon 13 & 1628_1630delAGA & del K543 & In-frame deletion & $\mathrm{N}$ domain & $\begin{array}{c}\text { PA } \\
\text { LGD }\end{array}$ \\
\hline 36 & $\mathrm{~F}$ & Moderate & $\begin{array}{l}\text { attempt. Investigations following } \\
\text { an episode of loss of } \\
\text { consciousness. }\end{array}$ & Exon 13 & 1697dupA & & Frameshift (PTC+1aa) & $\mathrm{N}$ domain & \\
\hline 37 & $\mathrm{~F}$ & Moderate & Major depressive disorder ${ }^{\mathrm{a}}$. & Exon 13 & 1713delAA & & Frameshift $(\mathrm{PTC}+4 \mathrm{aa})$ & $\mathrm{N}$ domain & LGD \\
\hline 38 & M & Mild & & Intron 13 & $1762-1 \mathrm{G}>\mathrm{C}$ & & Splice site & $\mathrm{N}$ domain & LGD \\
\hline 39 & M & Mild & & Exon 14 & 1919InsT & & Frameshift (PTC+4aa) & $\mathrm{P}$ domain & LGD \\
\hline 40 & $\mathrm{~F}$ & Moderate & $\begin{array}{l}\text { Major depressive disorder. } \\
\text { Investigations for fainting } \\
\text { episodes. }\end{array}$ & Exon 14 & 2017del C & & Frameshift (PTC+14aa) & $\mathrm{P}$ domain & LGD \\
\hline 41 & M & Moderate & Anxiety disorder NOS. & Exon 14 & 2046 Ins C & & Frameshift $(\mathrm{PTC}+2 \mathrm{aa})$ & $\mathrm{P}$ domain & LGD \\
\hline 42 & $\mathrm{~F}$ & Moderate & Investigations for blackouts. & Exon 14 & $2048 \mathrm{~A}>\mathrm{T}$ & K683M & Missense & $\mathrm{P}$ domain & PA \\
\hline 43 & $\mathrm{~F}$ & Moderate & & Intron 14 & $2098-2 A>C$ & & Splice site & $\mathrm{P}$ domain & LGD \\
\hline 44 & $\mathrm{~F}$ & Moderate & $\begin{array}{l}\text { Dysthymic disordera } \\
\text { Investigations for headaches. }\end{array}$ & Exon 15 & $2104 \mathrm{G}>\mathrm{A}$ & D702N & Missense & $\mathrm{P}$ domain & $\mathrm{PA}$ \\
\hline
\end{tabular}


Table 1 Clinical and neuropsychiatric features in 75 individuals with Darier Disease and type and location of ATP2A2 mutations

\begin{tabular}{|c|c|c|c|c|c|c|c|c|c|}
\hline ID & Sex & Severity of DD & Neuropsychiatric phenotype & Location & Nucleotide and alteration & Amino acid alteration & Type & Protein domain & $\begin{array}{c}\text { LGD or } \\
\text { PA } \\
\text { mutation }\end{array}$ \\
\hline 45 & M & Moderate & $\begin{array}{l}\text { Major depressive disorder }{ }^{\mathrm{a}} \text {. } \\
\text { Suicide attempt. }\end{array}$ & Exon 15 & $2116 \mathrm{G}>\mathrm{A}$ & $\mathrm{D} 706 \mathrm{~N}$ & Missense & $\mathrm{P}$ domain & $\mathrm{PA}$ \\
\hline 46 & M & Moderate & & Exon 15 & $2116 \mathrm{G}>\mathrm{A}$ & $\mathrm{D} 706 \mathrm{~N}$ & Missense & $\mathrm{P}$ domain & PA \\
\hline 47 & $\mathrm{~F}$ & Moderate & $\begin{array}{l}\text { Investigations for hearing } \\
\text { problems. }\end{array}$ & Exon15 & $2123 \mathrm{C}>\mathrm{A}$ & $\mathrm{P} 708 \mathrm{H}$ & Missense & $\mathrm{P}$ domain & PA \\
\hline 48 & M & Moderate & Major depressive disorder. & Exon 15 & $2249 \mathrm{G}>\mathrm{A}$ & $\mathrm{R} 750 \mathrm{Q}$ & Missense & S5 & PA \\
\hline $49^{\mathrm{b}}$ & $\mathrm{F}$ & Moderate & & Exon 15 & 2258del3bp & & In-frame deletion & S5 & PA \\
\hline 50 & $\mathrm{M}$ & Moderate & Depression NOS. & Exon 15 & $2287 \mathrm{C}>\mathrm{G}$ & L763V & Missense & S5 & PA \\
\hline 51 & M & Moderate & & Exon 15 & $2294 C>T$ & S765L & Missense & M5 & PA \\
\hline 52 & M & Moderate & $\begin{array}{l}\text { Investigations for loss of feeling } \\
\text { in lower limbs. }\end{array}$ & Exon 15 & $2294 \mathrm{C}>\mathrm{T}$ & S765L & Missense & M5 & PA \\
\hline 53 & M & Moderate & $\begin{array}{l}\text { Treatment for hearing problems. } \\
\text { Investigations for poor memory. }\end{array}$ & Exon 15 & $2300 A>G$ & N767S & Missense & M5 & PA \\
\hline 54 & $\mathrm{~F}$ & Moderate & $\begin{array}{l}\text { Major depressive disorder }{ }^{\mathrm{a}} \text {. } \\
\text { Investigations for blackouts. }\end{array}$ & Exon 15 & $2300 A>G$ & N767S & Missense & M5 & PA \\
\hline 55 & $\mathrm{~F}$ & Moderate & $\begin{array}{l}\text { Major depressive disorder. } \\
\text { Investigations for hearing } \\
\text { problems. }\end{array}$ & Exon 15 & $2300 A>G$ & N767S & Missense & M5 & PA \\
\hline 56 & $\mathrm{~F}$ & Mild & $\begin{array}{l}\text { Depression NOS. Investigations } \\
\text { for hearing problems. }\end{array}$ & Exon 15 & $2300 A>G$ & N767S & Missense & M5 & PA \\
\hline 57 & M & Mild & & Exon 15 & $2317 \mathrm{~T}>\mathrm{C}$ & C773R & Missense & M5 & PA \\
\hline 58 & $\mathrm{~F}$ & Moderate & $\begin{array}{l}\text { Depression NOS. Investigations } \\
\text { for headache and fainting } \\
\text { episodes. }\end{array}$ & Intron 15 & $2319-1 G>A$ & & Splice site & & LGD \\
\hline 59 & $\mathrm{~F}$ & Moderate & Anxiety disorder NOS. & Exon 16 & $2384 \mathrm{~A}>\mathrm{G}$ & N795S & Missense & M6 & PA \\
\hline 60 & $\mathrm{~F}$ & Moderate & Bipolar I disorder ${ }^{\mathrm{a}}$ & Exon 16 & $2405 \mathrm{C}>\mathrm{G}$ & P802R & Missense & M6 & PA \\
\hline 61 & $\mathrm{~F}$ & Moderate & Major depressive disorder. & Exon 16 & $2417 \mathrm{~T}>\mathrm{G}$ & L806R & Missense & M6 & PA \\
\hline 62 & $\mathrm{~F}$ & Severe & $\begin{array}{l}\text { Major depressive disorder }{ }^{\mathrm{a}} \text {. } \\
\text { Suicide attempt. Investigations for } \\
\text { blackouts. }\end{array}$ & Exon 17 & $2527 \mathrm{G}>\mathrm{T}$ & V843F & Missense & M7 & PA \\
\hline 63 & M & Moderate & & Exon 17 & 2584InsG & & Frameshift (PTC+14aa) & M7-M8 lumenal & LGD \\
\hline 64 & $\mathrm{~F}$ & Moderate & Major depressive disorder ${ }^{\mathrm{a}}$. & Exon 18 & $2620 \mathrm{C}>\mathrm{T}$ & Q874X & Nonsense & M7-M8 lumenal & LGD \\
\hline 65 & $\mathrm{~F}$ & Mild & Major depressive disorder. & Exon 18 & 2678dupC & & Frameshift $(\mathrm{PTC}+16 \mathrm{aa})$ & M7-M8 lumenal & LGD \\
\hline 66 & $\mathrm{M}$ & Moderate & Depression NOS. Suicide attempt. & Exon 18 & $2684 \mathrm{C}>\mathrm{T}$ & P895L & Missense & M7-M8 lumenal & PA \\
\hline 67 & $\mathrm{~F}$ & Moderate & & Exon18 & 2709 del 6bp & del V904 \& T905 & In-frame deletion & M8 & $\mathrm{PA}$ \\
\hline 68 & $\mathrm{~F}$ & Moderate & Depression NOS. & Exon 18 & 2730 Ins C & & Frameshift (PTC+71aa) & M8 & LGD \\
\hline 69 & $\mathrm{~F}$ & Moderate & & Exon 18 & $2741+1 G>T$ & & Splice site & & LGD \\
\hline
\end{tabular}


Table 1 Clinical and neuropsychiatric features in 75 individuals with Darier Disease and type and location of ATP2A2 mutations

\begin{tabular}{|c|c|c|c|c|c|c|c|c|c|}
\hline ID & Sex & Severity of DD & Neuropsychiatric phenotype & Location & Nucleotide and alteration & Amino acid alteration & Type & Protein domain & $\begin{array}{c}\text { LGD or } \\
\text { PA } \\
\text { mutation }\end{array}$ \\
\hline 70 & $\mathrm{~F}$ & Severe & $\begin{array}{l}\text { Major depressive disorder. } \\
\text { Investigations for blackouts. }\end{array}$ & Exon 18 & $2741+5 \mathrm{G}>\mathrm{C}$ & & Splice site & & LGD \\
\hline 71 & $\mathrm{~F}$ & Moderate & Depression NOS. & Exon 19 & $2759 \mathrm{C}>\mathrm{T}$ & S920F & Missense & $\begin{array}{c}\text { M8-M9 } \\
\text { Cytoplasmic }\end{array}$ & PA \\
\hline 72 & F & Severe & $\begin{array}{l}\text { Investigations for one-sided } \\
\text { weakness. }\end{array}$ & Exon 19 & $2759 \mathrm{C}>\mathrm{A}$ & S920Y & Missense & $\begin{array}{c}\text { M8-M9 } \\
\text { Cytoplasmic }\end{array}$ & PA \\
\hline 73 & M & Severe & $\begin{array}{l}\text { Medical notes report "adjustment } \\
\text { reaction" to relapse in } \mathrm{DD}^{\mathrm{a}, \mathrm{c}} \text {. }\end{array}$ & Exon 19 & $2759 \mathrm{C}>\mathrm{A}$ & S920Y & Missense & $\begin{array}{c}\text { M8-M9 } \\
\text { Cytoplasmic }\end{array}$ & PA \\
\hline 74 & $\mathrm{~F}$ & Mild & Cyclothymic disorder & Exon 19 & $2777 \mathrm{C}>\mathrm{G}$ & P926R & Missense & $\begin{array}{c}\text { M8-M9 } \\
\text { Cytoplasmic }\end{array}$ & PA \\
\hline 75 & $\mathrm{~F}$ & Moderate & $\begin{array}{l}\text { Treatment for meningitis } \\
\text { (unknown type). }\end{array}$ & Exon 20a & 2965del 7 Ins $9 \& 2983$ del A & & Frameshift $(\mathrm{PTC}+42 \mathrm{aa})$ & $\begin{array}{c}\text { M10-M11 } \\
\text { Cytoplasmic }\end{array}$ & LGD \\
\hline
\end{tabular}

${ }^{a}$ Requiring contact with psychiatric services, ${ }^{\mathrm{b}}$ mutation identified in previous study(Sakuntabhai, Ruiz-Perez, et al., 1999), ${ }^{\mathrm{c}}$ Classified as a maladjustment reaction as the patient was referred and seen by secondary psychiatric services, LGD = likely gene disrupting, PA = protein-altering, NOS = not otherwise specified, $\mathrm{S} n=$ stalk domains, M $n$; transmembrane domains, A domain= actuator domain, $\mathrm{N}$ domain $=$ nucleotide binding, $\mathrm{P}$ domain= phosphorylation domain . 
Table 2 Likely gene-disrupting (LGD) and protein-altering (PA) mutations among 75 individuals with and without the lifetime occurrence of neuropsychiatric phenotypes

\begin{tabular}{|c|c|c|c|c|c|c|c|c|c|c|c|c|c|c|c|c|c|c|c|c|}
\hline & \multicolumn{4}{|c|}{$\begin{array}{c}\text { Any neuropsychiatric } \\
\text { phenotype }\end{array}$} & \multicolumn{4}{|c|}{ Any psychiatric disorder } & \multicolumn{4}{|c|}{$\begin{array}{c}\text { Neurologist or } \\
\text { neurological procedure }\end{array}$} & \multicolumn{4}{|c|}{ Suicide attempt } & \multicolumn{4}{|c|}{$\begin{array}{c}\text { Severe neuropsychiatric } \\
\text { phenotype }\end{array}$} \\
\hline & \multicolumn{2}{|c|}{ Yes } & \multicolumn{2}{|c|}{ No } & \multicolumn{2}{|c|}{ Yes } & \multicolumn{2}{|c|}{ No } & \multicolumn{2}{|c|}{ Yes } & \multicolumn{2}{|c|}{ No } & \multicolumn{2}{|c|}{ Yes } & \multicolumn{2}{|c|}{ No } & \multicolumn{2}{|c|}{ Yes } & \multicolumn{2}{|c|}{ No } \\
\hline & $\mathrm{N}$ & $\%$ & $\mathrm{~N}$ & $\%$ & $\mathrm{~N}$ & $\%$ & $\mathrm{~N}$ & $\%$ & $\mathrm{~N}$ & $\%$ & $\mathrm{~N}$ & $\%$ & $\mathrm{~N}$ & $\%$ & $\mathrm{~N}$ & $\%$ & $\mathrm{~N}$ & $\%$ & $\mathrm{~N}$ & $\%$ \\
\hline LGD & 25 & 45.5 & 7 & 35 & 19 & 46 & 13 & 38 & 16 & 53 & 16 & 36 & 5 & 50 & 25 & 41 & 3 & 75 & 29 & 41 \\
\hline PA & 30 & 54.5 & 13 & 65 & 22 & 54 & 21 & 62 & 14 & 47 & 29 & 64 & 5 & 50 & 36 & 59 & 1 & 25 & 42 & 59 \\
\hline Total N* & \multicolumn{4}{|c|}{$\begin{array}{cl}55 & 20 \\
\chi^{2}=0.655, \mathrm{df}=1, \mathrm{p}= & 0.418\end{array}$} & \multicolumn{4}{|c|}{$\begin{array}{cc}41 & 34 \\
\chi^{2}=0.499, d f=1, p=0.480\end{array}$} & \multicolumn{4}{|c|}{$\begin{array}{cc}30 & 45 \\
\chi^{2}=2.326, d f=1, p= & 0.127\end{array}$} & \multicolumn{4}{|c|}{ Fisher's, $p=0.733$} & \multicolumn{3}{|c|}{ Fisher's $p=0.307$} & \\
\hline
\end{tabular}

*Ns vary due to unknown data 
Table 3 Combined analysis with previously reported cases/families in the literature $(n=384)$ : comparison of mutation type and location according to the absence or presence of a reported severe neuropsychiatric phenotype (bipolar disorder, schizophrenia or affective psychosis)

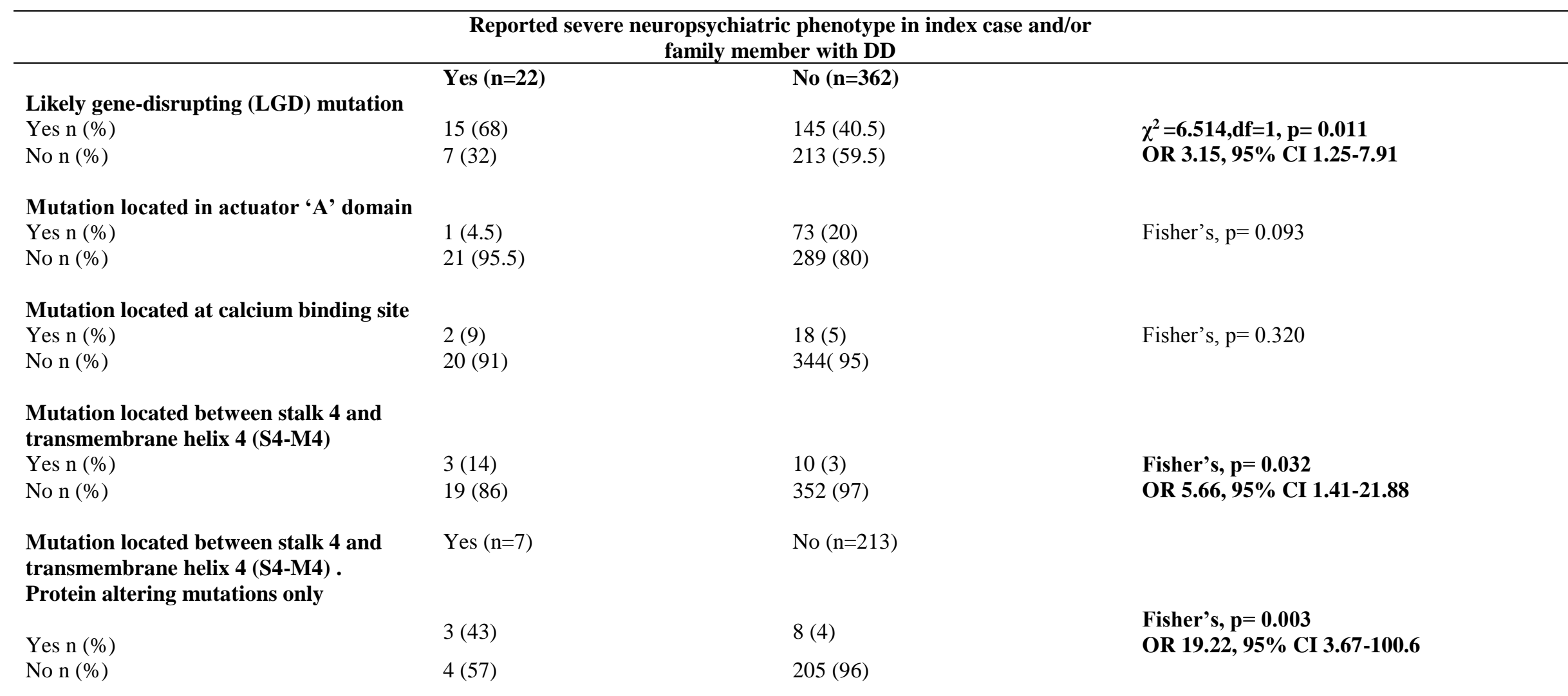

$\mathrm{DD}=$ Darier disease, $\mathrm{OR}=$ odds ratio, $\mathrm{CI}=$ confidence interval. Ns vary due to four mutations in the literature that could not be classified according to type due to unknown function. 
FIGURE 1 Comparison of prevalence of likely gene-disrupting (LGD) and protein-altering (PA) mutations among 75 individuals with and without the lifetime occurrence of neuropsychiatric phenotypes

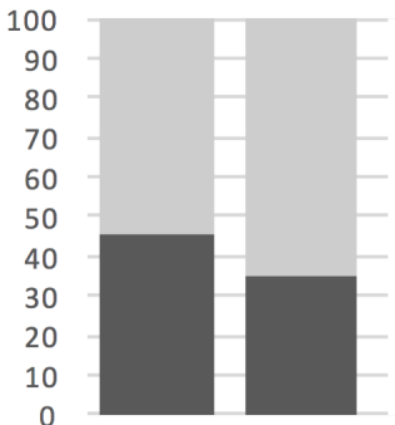

Yes

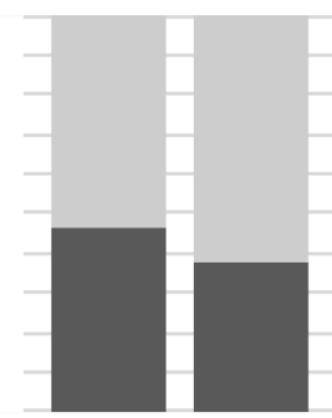

Yes

No

Any psychiatric disorder

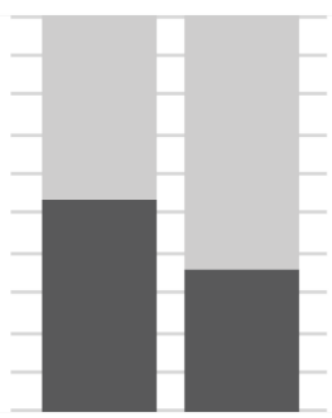

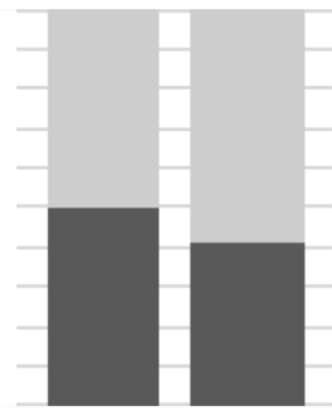

Yes$$
\text { No }
$$

Any neuropsychiatric phenotype

$$
\begin{aligned}
& \text { Yes No } \\
& \begin{array}{c}
\text { Neurologist or neurological } \\
\text { procedure }
\end{array} \\
& \text { - LGD } \square \text { PA }
\end{aligned}
$$$$
\text { Suicide attempt }
$$

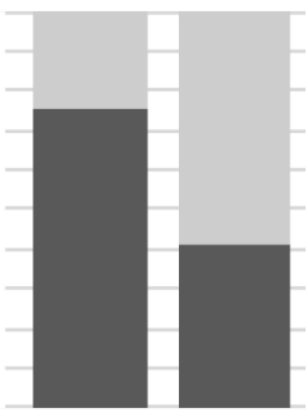

Yes

No Severe neuropsychiatric phenotype 
FIGURE 2 Key observations of evidence for possible clustering of mutations within the SERCA2b protein among 75 individuals with similar neuropsychiatric phenotypes

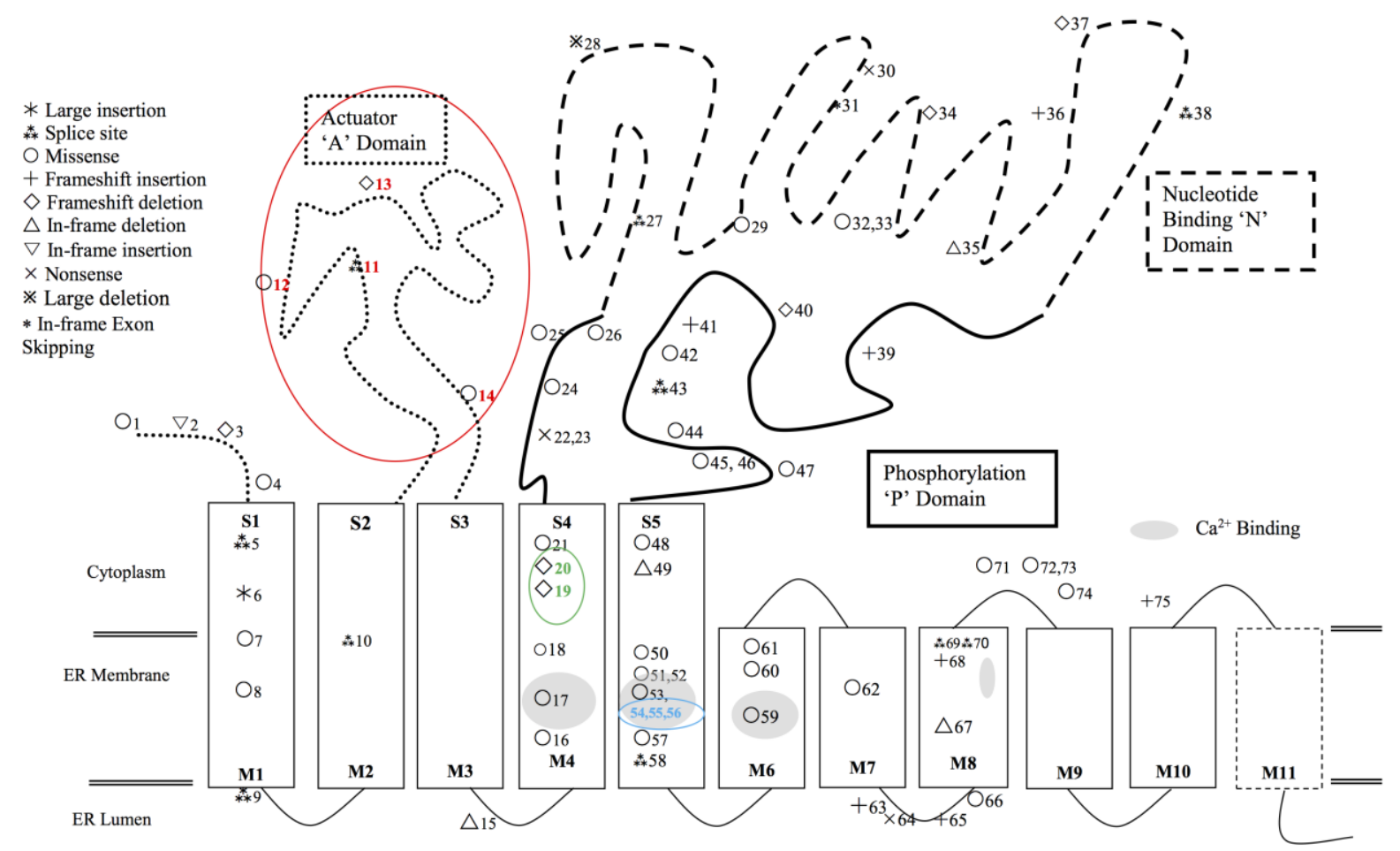


FIGURE 3 All known neuropsychiatric features in individuals/families with Darier disease causing mutations in the S4-M4 domain of SERCA2 including cases in current study

$\mathrm{ER}=$ Endoplasmic reticulum, $\mathrm{S}=$ stalk domain, $\mathrm{M}=$ transmembrane domain, NOS=not otherwise specified. Mutations have been found to be unique to families, except for mutations marked ${ }^{2}$ where mutations have been reported in two unrelated families.

${ }^{a}$ Unpublished mutation identified in an individual with DD seen by our research group who was not included in the current study.

'Parent of index was admitted to psychiatric hospital with 'high mood' although neither parent was reported to have DD.

All mutations are located in Exon 8.

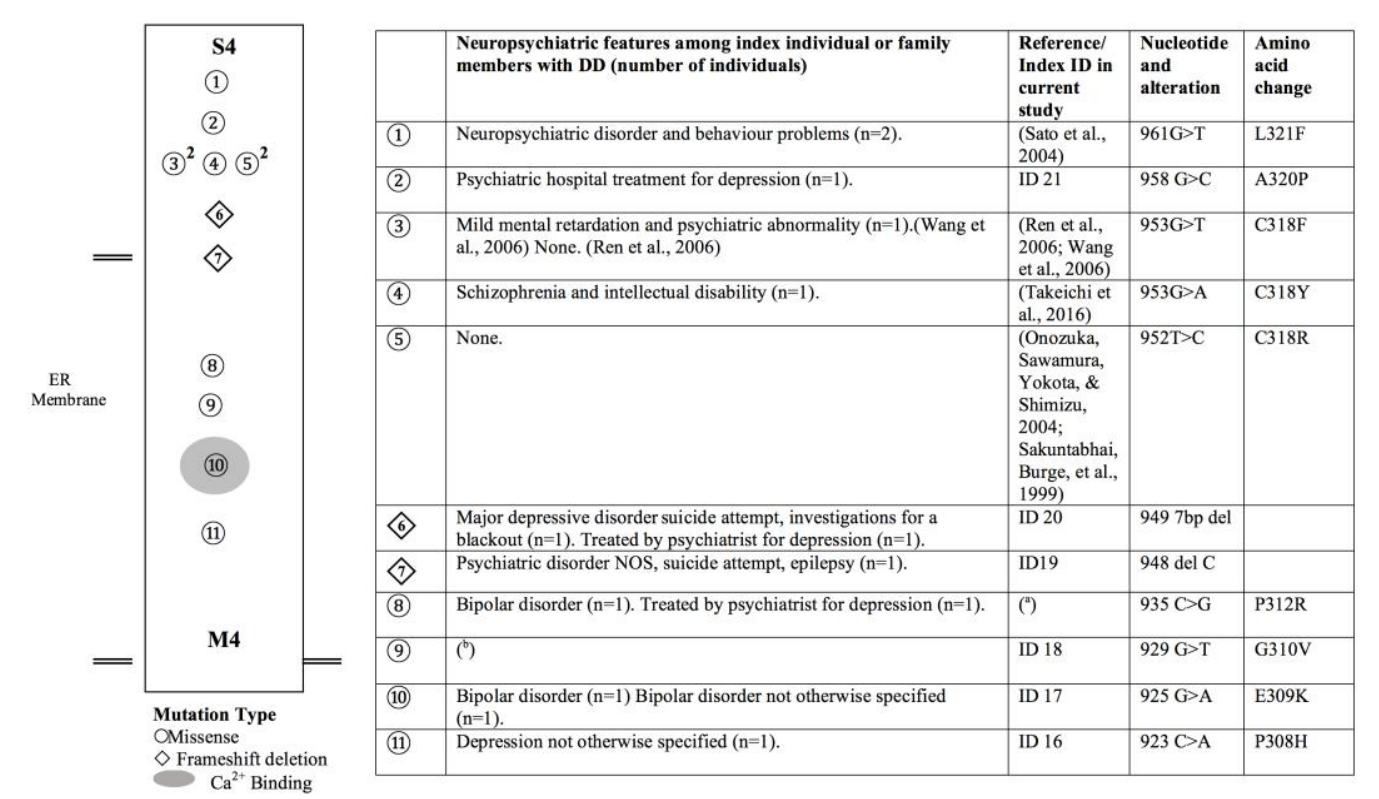




\section{REFERENCES}

American Psychiatric Association. (2000). Diagnostic and Statistical Manual of Mental Disorders (Fourth Edition, Text Revision). Washington, DC: APA.

Bchetnia, M., Charfeddine, C., Kassar, S., Zribi, H., Guettiti, H. T., Ellouze, F., ... Mokni, M. (2009). Clinical and mutational heterogeneity of Darier disease in Tunisian families. Archives of Dermatology, 145(6), 654-6. http://doi.org/10.1001/archdermatol.2009.52

Berridge, M. J. (2002). The endoplasmic reticulum: a multifunctional signaling organelle. Cell Calcium, 32(5-6), 235-249.

Berridge, M. J., Bootman, M. D., \& Lipp, P. (1998). Calcium--a life and death signal. Nature, 395(6703), 645-648.

Breen, M. S., White, C. H., Shekhtman, T., Lin, K., Looney, D., Woelk, C. H., \& Kelsoe, J. R. (2016). Lithium-responsive genes and gene networks in bipolar disorder patient-derived lymphoblastoid cell lines. The Pharmacogenomics Journal, 16(5), 446-453. http://doi.org/10.1038/tpj.2016.50

Burge, S. M., \& Wilkinson, J. D. (1992). Darier-White disease: a review of the clinical features in 163 patients. J Am Acad Dermatol, 27(1), 40-50.

Cederlöf, M., Bergen, S., Långström, N., Larsson, H., Boman, M., Craddock, N., ... Lichtenstein, P. (2015). The association between Darier disease, bipolar disorder, and schizophrenia revisited: A population-based family study. Bipolar Disorders, 17(3), 340-344. http://doi.org/10.1111/bdi.12257

Cederlöf, M., Karlsson, R., Larsson, H., Almqvist, C., Magnusson, P. K. E., Nordlind, K., ... Lichtenstein, P. (2015). Intellectual disability and cognitive ability in Darier disease: Swedish nation-wide study. British Journal of Dermatology, 173(1), 155158. http://doi.org/10.1111/bjd.13740

Cross-Disorder Group of the Psychiatric Genomics Consortium, \& Genetic Risk Outcome of Psychosis (GROUP) Consortium. (2013). Identification of risk loci with shared effects on five major psychiatric disorders: a genome-wide analysis. Lancet, 381, 1371-1379. http://doi.org/10.1016/S0140-6736(12)62129-1

Denicoff, K., Lehman, Z., Rubinow, D., Schmidt, P., \& Peck, G. (1990). Suicidal ideation in Darier's disease. J Am Acad Dermatol, 22(2 Pt 1), 196-198.

Dodiuk-Gad, R., Cohen-Barak, E., Khayat, M., Milo, H., Amariglio-Diskin, L., DanialFaran, N., ... Shalev, S. (2016). Darier disease in Israel: Combined evaluation of genetic and neuropsychiatric aspects. British Journal of Dermatology, 174(3), 562568. http://doi.org/10.1111/bjd.14220

Dodiuk-Gad, R., Lerner, M., Breznitz, Z., Cohen-Barak, E., Ziv, M., Shani-Adir, A., ... Rozenman, D. (2014). Learning disabilities in Darier's disease patients. Journal of the European Academy of Dermatology and Venereology, 28(3), 314-319. http://doi.org/10.1111/jdv.12103

Ferreira, M. A. R., O’Donovan, M. C., Meng, Y. A., Jones, I. R., Ruderfer, D. M., Jones, L., ... Craddock, N. (2008). Collaborative genome-wide association analysis supports a role for ANK3 and CACNA1C in bipolar disorder. Nature Genetics, 40, 1056-1058. http://doi.org/10.1038/ng.209

Gordon-Smith, K., Jones, L. A., Burge, S. M., Munro, C. S., Tavadia, S., \& Craddock, N. (2010). The neuropsychiatric phenotype in Darier disease. British Journal of Dermatology, 163(3), 515-522. http://doi.org/10.1111/j.1365-2133.2010.09834.x

Green, E. K., Gordon-Smith, K., Burge, S. M., Grozeva, D., Munro, C. S., Tavadia, S., ... Craddock, N. (2013). Novel ATP2A2 mutations in a large sample of individuals 
with Darier disease. Journal of Dermatology, 40(4), 259-266.

http://doi.org/10.1111/1346-8138.12082

Hayashi, A., Kasahara, T., Kametani, M., Toyota, T., Yoshikawa, T., \& Kato, T. (2009). Aberrant endoplasmic reticulum stress response in lymphoblastoid cells from patients with bipolar disorder. The International Journal of Neuropsychopharmacology, 12(1), 33. http://doi.org/10.1017/S1461145708009358

Jacobsen, N. J., Lyons, I., Hoogendoorn, B., Burge, S., Kwok, P. Y., O’Donovan, M. C., ... Owen, M. J. (1999). ATP2A2 mutations in Darier's disease and their relationship to neuropsychiatric phenotypes. Hum Mol Genet, 8(9), 1631-1636.

Medansky, R. S., \& Woloshin, A. A. (1961). Darier's disease. An evaluation of its neuropsychiatric component. Arch Dermatol, 84, 482-484.

Munro, C. S. (1992). The phenotype of Darier's disease: penetrance and expressivity in adults and children. Br J Dermatol, 127(2), 126-130.

Nakamura, T., Kazuno, A. A., Nakajima, K., Kusumi, I., Tsuboi, T., \& Kato, T. (2016). Loss of function mutations in ATP2A2 and psychoses: A case report and literature survey. Psychiatry and Clinical Neurosciences, 70(8), 342-350. http://doi.org/10.1111/pcn.12395

Nellen, R. G. L., Steijlen, P. M., van Steensel, M. A. M., Vreeburg, M., Frank, J., van Geel, M., \& van Geel, M. (2016). Mendelian Disorders of Cornification Caused by Defects in Intracellular Calcium Pumps: Mutation Update and Database for Variants in ATP2A2 and ATP2C1 Associated with Darier Disease and Hailey-Hailey Disease. Human Mutation, 1-14. http://doi.org/10.1002/humu.23164

Pfaffenseller, B., Wollenhaupt-Aguiar, B., Fries, G. R., Colpo, G. D., Burque, R. K., Bristot, G., ... Kapczinski, F. (2014). Impaired endoplasmic reticulum stress response in bipolar disorder: cellular evidence of illness progression. The International Journal of Neuropsychopharmacology, 17(9), 1453-1463. http://doi.org/10.1017/S1461145714000443

Ringpfeil, F., Raus, A., DiGiovanna, J. J., Korge, B., Harth, W., Mazzanti, C., ... Richard, G. (2001). Darier disease--novel mutations in ATP2A2 and genotypephenotype correlation. Exp Dermatol, 10(1), 19-27.

Ripke, S., Neale, B. M., Corvin, A., Walters, J. T. R., Farh, K.-H., Holmans, P. a., ... O'Donovan, M. C. (2014). Biological insights from 108 schizophrenia-associated genetic loci. Nature, 511, 421-427. http://doi.org/10.1038/nature13595

Ruiz-Perez, V. L., Carter, S. A., Healy, E., Todd, C., Rees, J. L., Steijlen, P. M., ... Strachan, T. (1999). ATP2A2 mutations in Darier's disease: variant cutaneous phenotypes are associated with missense mutations, but neuropsychiatric features are independent of mutation class. Hum Mol Genet, 8(9), 1621-1630.

Sakuntabhai, A., Burge, S., Monk, S., \& Hovnanian, A. (1999). Spectrum of novel ATP2A2 mutations in patients with Darier's disease. Hum Mol Genet, 8(9), 16111619.

Sakuntabhai, A., Ruiz-Perez, V., Carter, S., Jacobsen, N., Burge, S., Monk, S., ... Hovnanian, A. (1999). Mutations in ATP2A2, encoding a Ca2+ pump, cause Darier disease. Nat Genet, 21(3), 271-277.

Savignac, M., Simon, M., Edir, A., Guibbal, L., \& Hovnanian, A. (2014). SERCA2 Dysfunction in Darier Disease Causes Endoplasmic Reticulum Stress and Impaired Cell-to-Cell Adhesion Strength: Rescue by Miglustat. Journal of Investigative Dermatology, 134, 1961-1970. http://doi.org/10.1038/jid.2014.8

So, J., Warsh, J. J., \& Li, P. P. (2007). Impaired Endoplasmic Reticulum Stress Response in B-Lymphoblasts From Patients With Bipolar-I Disorder. Biol Psychiatry, 62(2), 141-147. 
Svendsen, I. B., \& Albrectsen, B. (1959). The prevalence of dyskeratosis follicularis (Darier's disease) in Denmark: an investigation of the heredity in 22 families. Acta Derm Venereol, 39, 256-269.

Tavadia, S., Mortimer, E., \& Munro, C. S. (2002). Genetic epidemiology of Darier's disease: a population study in the west of Scotland. Br J Dermatol, 146(1), 107-109.

Verkhratsky, A. (2005). Physiology and Pathophysiology of the Calcium Store in the Endoplasmic Reticulum of Neurons. Physiological Reviews, 85, 201-280.

Wing, J. K., Babor, T., Brugha, T., Burke, J., Cooper, J. E., Giel, R., ... Sartorius, N. (1990). SCAN. Schedules for Clinical Assessment in Neuropsychiatry. Archives of General Psychiatry, 47(6), 589-93. 